\title{
The relative abundance of invasive House Sparrows (Passer domesticus) in an urban environment in South Africa is determined by land use
}

\author{
Kholosa Magudu ${ }^{1,2}$ \& Colleen T. Downs ${ }^{1 *}$ \\ ${ }^{1}$ DST-NRF Centre for Invasion Biology, School of Life Sciences, University of KwaZulu-Natal, \\ Private Bag X01, Scottsville, Pietermaritzburg, 3209 South Africa. \\ ${ }^{2}$ Invasive Species Programme, South African National Biodiversity Institute, Cape Town. \\ Received 17 September 2014. To authors for revision 29 January 2015. Accepted 20 March 2015
}

\begin{abstract}
The House Sparrow, Passer domesticus, is invasive in many areas of the world, but is listed as a species of conservation concern in parts of its native range. This study assessed the effect of land-use type on the relative abundance of House Sparrows in Pietermaritzburg, South Africa, an urban area where they are invasive. It was predicted that House Sparrows in an urban environment would be more abundant at shopping malls compared with other habitats. Spot counts were done at shopping malls, schools, factories and suburban gardens throughout the year. House Sparrows were recorded frequently at shopping malls and rarely in suburban gardens. Type of urban land use appears to determine food and possibly nest site availability. This in turn affects the density, relative abundance, and distribution of House Sparrows. There appears no need to regulate this urban House Sparrow population because it has different feeding and breeding requirements to native birds, is not predatory, and is largely restricted to heavily transformed landscapes.
\end{abstract}

Key words: alien invasive, House Sparrow, land-use type, Passer domesticus, relative abundance, resource availability, urban environment.

\section{INTRODUCTION}

Birds are important indicators of how urbanization modifies the composition and structure of natural habitats (Bonier, Martin \& Wingfield, 2007; Reis, López-Iborra \& Pinheiro, 2012). Urban land-use types provide habitat heterogeneity and many different niches (Shaw, Chamberlain \& Evans, 2011) in the form of gardens, industrial parks, malls and indigenous remnants. Habitat structure is one of the fundamental environmental factors that contribute to the survival of avian fauna in urban gradients determining the availability of food and nest-sites (Fuller et al., 2008). Urban gardens offer trees for nesting, bird feeders, and bird baths for drinking water (Aitkenhead, Peterson \& Volder, 2010; Fuller et al., 2008). Therefore, some urban ecosystems allow certain bird species to persist (Aitkenhead-Peterson \& Volder, 2010); while characteristics of other urban habitats lead to a reduction in bird species diversity (Fernández-Juricic \& Jokimäki, 2001). Reis et al. (2012) reported that bird species richness in natural ecosystems was higher than in urbanized areas in Central Brazil. In

*To whom correspondence should be addressed.

E-mail: downs@ukzn.ac.za particular, avian species that respond negatively to increased levels of urbanization include habitat specialists and species with narrow environmental tolerance (Bonier et al., 2007). Conversely, the opposite is true for alien birds; many of these species have not only adapted but invaded many habitat niches (Kark et al. 2007). In southern Africa examples include the Common Myna (Acridotheres tristis), Feral Pigeon (Columba livia), House Crow (Corvus splendens) and House Sparrow (Passer domesticus) (Dean, 2000, 2005; Peacock, Van Rensburg \& Robertson, 2007; Sol et al., 2011).

Many passerine species have been successful alien invaders worldwide (Dean, 2000). In southern Africa, passerine species comprise $90 \%$ of all successful alien invasive birds (Dean, 2000). A variety of reasons have been suggested for the high abundance of both indigenous and alien passerines in urban environments (Liker et al., 2008). A key feature is that most tend to become generalists or opportunists (Dean, 2000; Bonier et al., 2007). They successfully adapt by exploiting available resources and utilizing all anthropogenic 'habitats' such as roofs, gutters and trees (Kark et al., 2007; Peacock et al., 2007). 


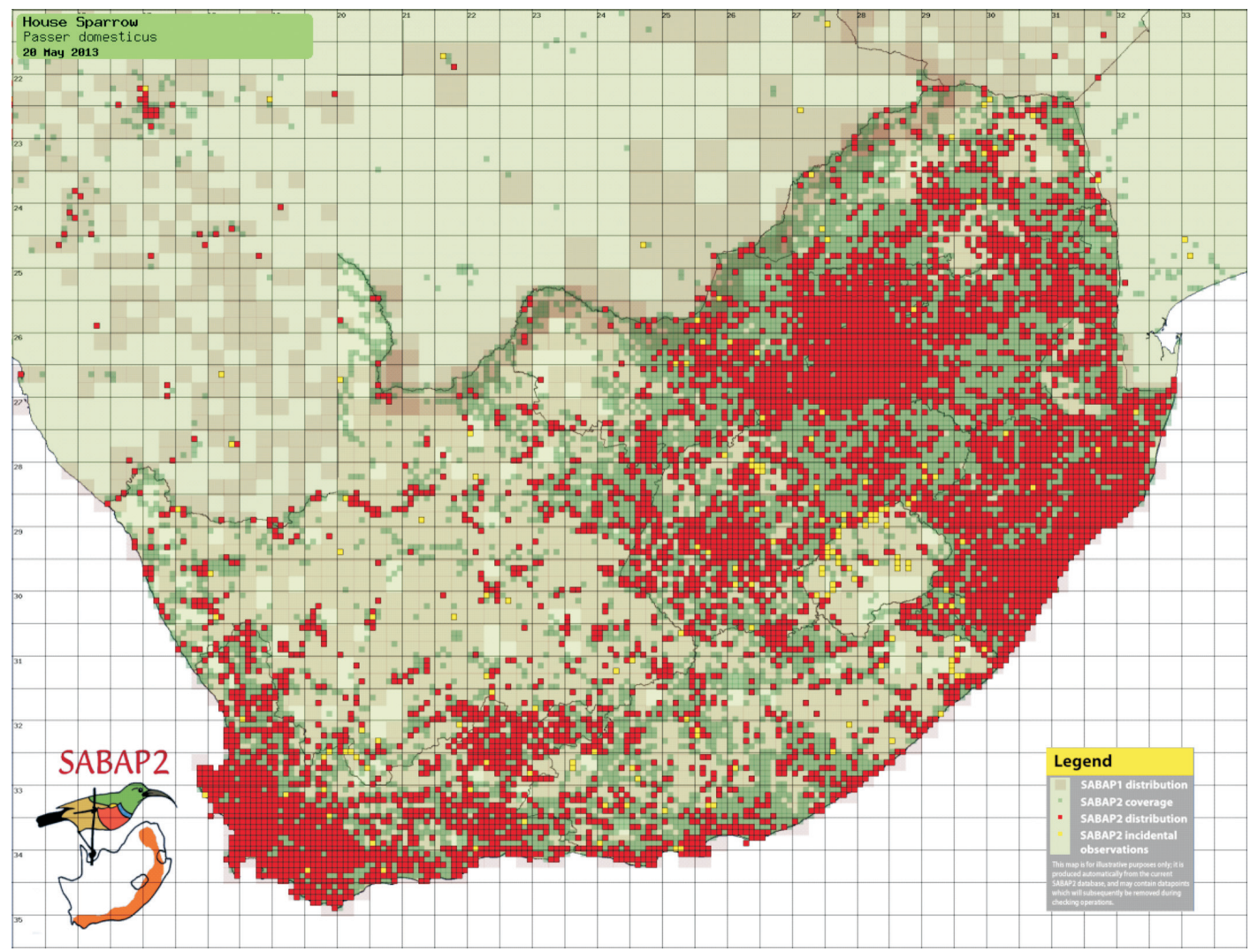

Fig. 1. The recorded distribution of the house sparrow showing range expansion in South Africa, from SABAP 2, May 2013 (Image source: sabap2.adu.org.za).

The House Sparrow is a classic example of a successful human commensal worldwide (Chamberlain et al., 2007; De Laet \& Summers-Smith, 2007). It is deemed an invasive alien bird in many countries, including South Africa (Fig. 1), and is a good example of an opportunist that adopts a 'whatever is available should be used' attitude (Dean, 2000). Despite their past success, House Sparrow populations have decreased dramatically in urban areas in their native range in Europe (Chamberlain et al., 2007; De Laet \& SummersSmith, 2007; Seress et al., 2012). Consequently, this species has become a bird of special conservation concern, especially in Britain (Shaw et al., 2011, Seress et al., 2012). No study has fully explored the causes for the shrinkage of House Sparrow ranges (Kark et al., 2007) but it is likely due to multiple negative factors (Seress et al., 2012).

The aim of this study was to assess the effect of land-use type on the relative abundance of House
Sparrows in an urban environment. We predicted that House Sparrows would be most abundant at shopping malls compared with other habitats due to increased food and roost availability.

\section{METHODS}

\section{Data collection}

Different habitat types were identified within the city of Pietermaritzburg $\left(29^{\circ} 37^{\prime} \mathrm{S}, 30^{\circ} 23^{\prime} \mathrm{E}\right)$ and surrounding suburban areas which comprise the Msunduzi Municipality, KwaZulu-Natal, South Africa. Schools $(n=10)$, shopping malls $(n=10)$, and factories or industrial parks $(n=10)$ were surveyed (Fig. 2). A pilot study revealed that sampling House Sparrows in the residential suburbs was challenging due to obstructed visibility and difficulty in accessing properties. Consequently, 20 suburban households were requested to monitor the total number of House Sparrows that visited their gardens on a monthly basis. Home 


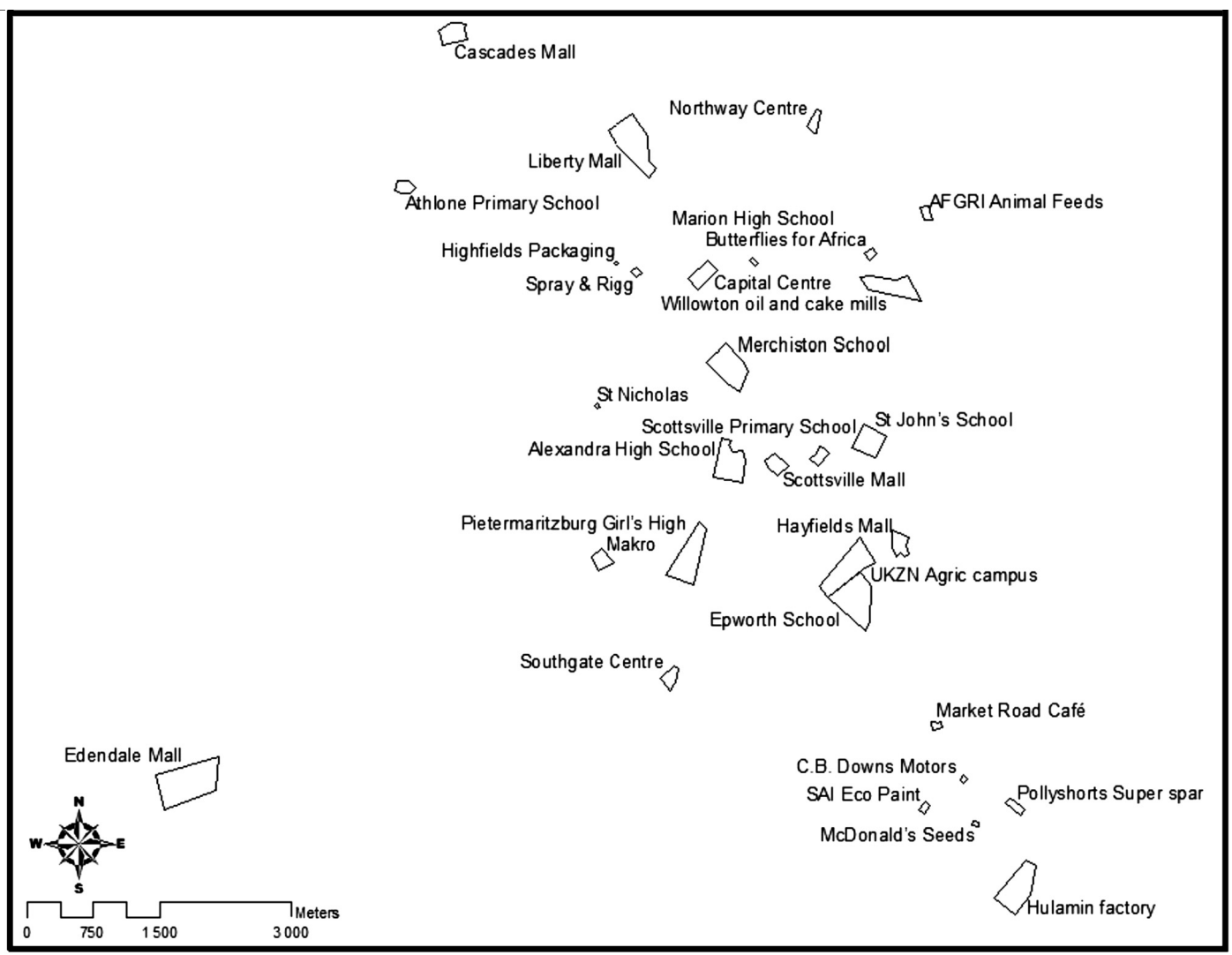

Fig. 2. Distribution of the selected House Sparrow study sites in Pietermaritzburg.

owners were given a standard datasheet to record House Sparrow information.

Data collection commenced in April 2012 and was completed in September 2012. Observations started in the early morning (06:00-09:00). On ten sampling days each month three sites were visited per day, so that each of the 30 sites was visited once every month. We counted all House Sparrows in $20 \mathrm{~min}$ at each site (Gutzwiller, 1991) to give a total count for that site. At each site all House Sparrows observed were counted by the same observer. Birds flying over the station were not recorded.

\section{Analyses}

STATISTICA 7 (Statsoft Inc, Tulsa, U.S.A.) was used to analyse the data. Since birds were counted monthly at the same sites for six months, Generalized Linear Models (GLM) and Repeated Measures of ANOVA (RMANOVA) were used to analyse the effects of land-use type on the relative abundance of House Sparrows. Population density calculations were derived from area estimates of each site and the total count per site. Tukey's HSD post hoc tests were run to examine significant differences in the total House Sparrow count under varied land-use types during the six-month period. Similar analyses were done for House Sparrow density. ArcGIS Desktop version 9.3.1 (ESRI, California) was used to calculate the area of each site and compose a map showing the House Sparrow study sites in Pietermaritzburg (Fig. 2).

\section{RESULTS}

There were significant effects of land-use type on House Sparrow counts and relative abundance throughout the six months of sampling $\left(F_{15,170}=\right.$ 2.02, $P<0.05$, Fig. 3). A post hoc Tukey's HSD test showed significant monthly differences in House Sparrow counts between shopping malls and houses. In addition, significant differences in total counts were observed between schools and shopping malls, but not throughout the sampling period. Within land-use type, the total counts in shopping malls during April and May were significantly 


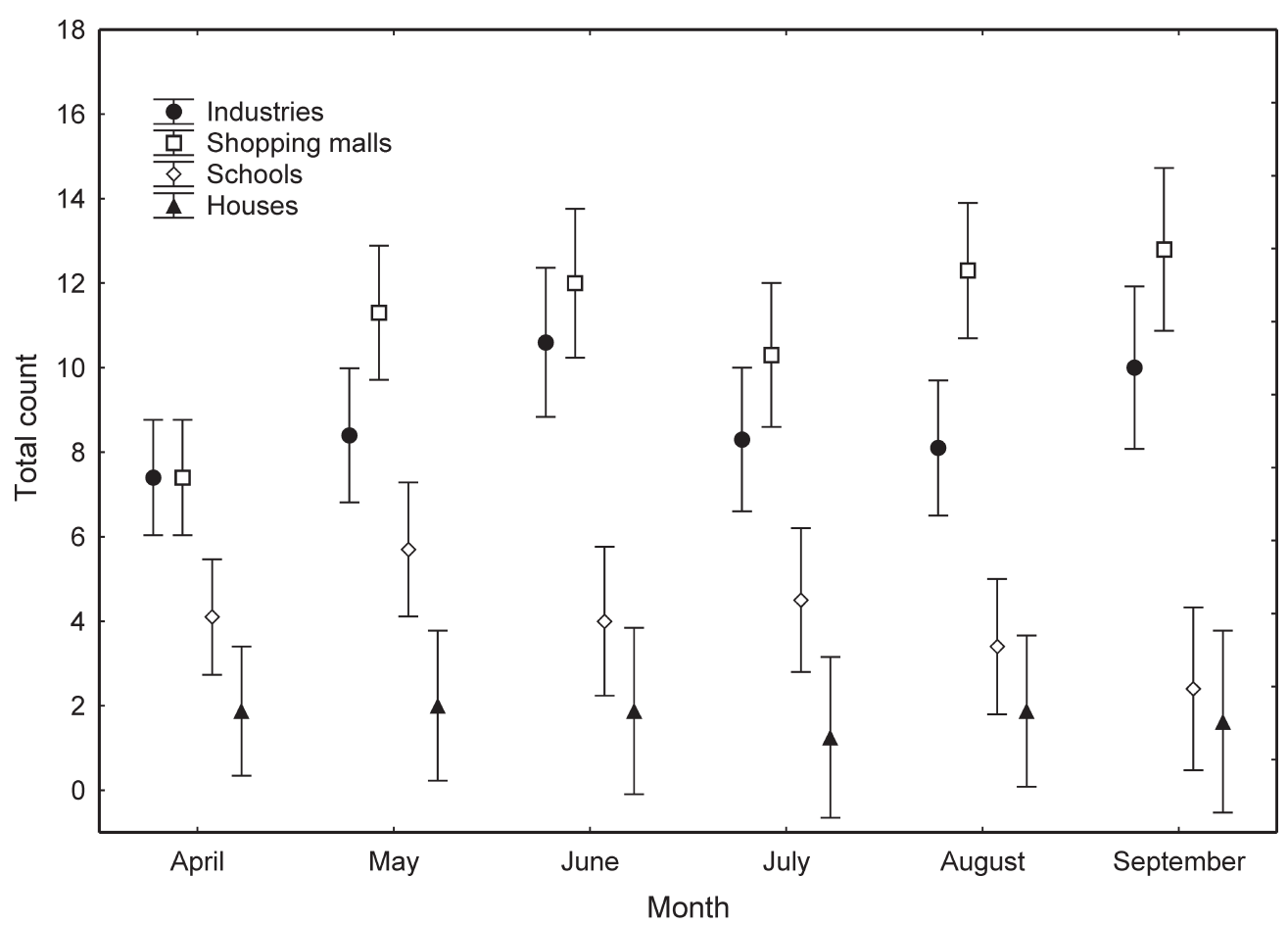

Fig. 3. Total House Sparrow counts (mean \pm S.E.) per month in four different urban land-use types.

higher than during August and September.

On average, total counts of House Sparrows in shopping malls were the highest $(12.8 \pm 14.72$ (mean \pm S.E.) birds per month), while counts at houses were significantly lower $(2.00 \pm 3.77$ birds per month). Industrial sites had House Sparrow counts equal to shopping malls in some months (Fig. 3). However, total counts in industrial sites were much higher (10.6 \pm 12.36 House Sparrows per month) than for houses and schools ( $5.7 \pm 7.29$ House Sparrows per month). The effects of urban land-use types on House Sparrow densities were insignificant throughout the six months of sampling $\left(F_{15180}=0.95, P>0.05\right)$.

\section{DISCUSSION}

Buildings are a key habitat feature for House Sparrows (Dean, 2000, 2005; Chamberlain et al. 2007; McCaffrey \& Mannan, 2012). Bird densities, particularly of introduced species, can be high in urban areas (Beissinger \& Osborne, 1982), most likely due to greater food abundance and the availability of nesting sites (Yap \& Sodhi, 2004). Similar studies on House Sparrow populations confirm that the availability of buildings in urban and suburban areas is a good predictor of House Sparrow densities (Chamberlain et al., 2007;
Robinson, Siriwardena \& Crick, 2005). Their nests vary with location in South Africa but most are in holes in buildings, under eaves, in thatched roofs, or in creepers on buildings (Dean, 2005).

The main findings of this study support the prediction that House Sparrow occurrence was affected by land-use type in an urban environment. Type of urban land use appears to determine food and possibly nest site availability. This in turn affects the density, relative abundance, and distribution of House Sparrows. They are renowned human commensals (Dean, 2005; Chamberlain et al., 2007; De Laet \& Summers-Smith, 2007), but were also abundant in industrial areas where they had roost sites and fed on left-over food (especially where small industries had outdoor dining tables (K.M. pers. obs.). At sites with grain storage, House Sparrows, along with Feral and indigenous Pigeons, were attracted by seed spillage (K.M. pers. obs.). In most of the shopping malls in the parking lots people regularly fed the birds either intentionally or unintentionally (K.M. pers. obs.) and there was spillage from cafeterias and food outlets. Consequently, shopping malls and industrial areas had the highest concentration of House Sparrows in Pietermaritzburg. House Sparrows in Kenya showed behavioural flexibility with some 
eating more novel foods (Liebl \& Martin, 2014). This individual foraging variation is likely to be important in variable environments and thereby facilitates range expansion (Liebl \& Martin, 2014).

House sparrow densities appeared similar in all land-use types in our analysis. However, direct observations by the home owners revealed that House Sparrows were rarely sighted in their gardens and moved over several properties. Although the results of all land-use types are shown together (Fig. 3), we are aware that the data are difficult to compare directly across land uses since there is a high level of subjectivity associated with the bird count data from households. This is because the counting effort at houses was not standardized, and data collection there was carried out by different individuals. However, as total counts were done and numbers at residential sites low, we think the comparison shows the current trends.

The House Sparrows in this study may have used resources across an entire street or neighbourhood (McCaffrey \& Mannan, 2012). The majority of the homeowners who provided House Sparrow data did not have feeding tables for birds in their gardens and most gardens lacked trees, and had large surface areas of lawn and concrete. Recent studies in North America have shown that birds visit unvegetated urban yards infrequently (McCaffrey \& Mannan, 2012).

Food for granivores in urban environments includes sources such as bird feeders, alien vegetation and refuse, with refuse the most abundant food source. Refuse, however, provides limited food options for nestlings compared to natural food sources (Aitkenhead-Peterson \& Volder, 2010). House Sparrows have a high demand for food particularly in winter because their ability to cope with cold temperatures relies on a constant food supply (Nzama, Downs \& Brown, 2010). House Sparrows have extensive phenotypic flexibility to adjust their basal metabolic rates to tolerate cold conditions based on work done on local birds (Nzama et al., 2010).

According to Sol et al. (2012), the success of alien birds as invaders depends not on physiological mechanisms but on their ability to increase their reproductive output. The energy required for reproduction and growth depends largely on the availability of food (Sol et al., 2012). House sparrows regularly use man-made structures as nest sites (Dean, 2000, 2005; pers. obs.). Unlike other invasive birds such as Rose-ringed Parakeets (Psittacula krameri) they do not appear to compete with native bird species for nesting sites and food sources, ultimately displacing them (Sol et al., 2011). House Sparrows are opportunistic feeders, and were dominated by other aggressive invasive alien birds such as the Common Myna. Based on our observations, House Sparrows pose no threat to biodiversity in Pietermaritzburg.

\section{ACKNOWLEDGEMENTS}

M. Brown is thanked for technical assistance. $\mathrm{J}$. Wilson is thanked for his insightful guidance, and J. Butler for proofreading. M. Witteveen and several others were instrumental in tireless fieldwork efforts. We would like to acknowledge the help of P. Singh in the GIS-related work and many postgraduates including those who assisted with driving. Business and property owners, including school principals and home-based monitors are thanked for their co-operation. This work was supported by the South African Department of Environment Affairs' Working for Water (WfW) Programme through its funding of the South African National Biodiversity Institute's Invasive Species Programme. We are grateful for the comments of the reviewers.

\section{REFERENCES}

Aitkenhead-Peterson, J. \& Volder, A. (2010). Birds in urban ecosystems: population dynamics, community structure, biodiversity and conservation. Agronomy Monograph, 55, 75-86.

Beissinger, S.R. \& Osborne, D.R. (1982). Effects of urbanization on avian community organization. Condor, 84, 75-83.

Bonier, F., Martin, P.R. \& Wingfield, J.C. (2007). Urban birds have broader environmental tolerance. Biology Letters, 3, 670-673.

Chamberlain, D., Toms, M., Cleary-McHarg, R. \& Banks, A. (2007). House sparrow (Passer domesticus) habitat use in urbanized landscapes. Journal of Ornithology, 148, 453-462.

De Laet, J. \& Summers-Smith, D.J. (2007). The status of the urban house sparrow Passer domesticus in north-western Europe: a review. Journal of Ornithology, 148, 275-278.

Dean, W.R.J. (2000). Alien birds in southern Africa: what factors determine success? South African Journal of Science, 96, 9-14.

Dean, W.R.J. (2005). House sparrow. In P.A.R. Hockey, W.R.J. Dean \& P.G. Ryan (Eds) Roberts birds of southern Africa, VIIth edn., (pp.1082-1083). Cape Town, South Africa: John Voelker Bird Book Fund.

Fernández-Juricic, E. \& Jokimäki, J. (2001). A habitat island approach to conserving birds in urban landscapes: case studies from southern and northern Europe. Biodiversity and Conservation, 10, 20232043.

Fuller, R.A., Warren, P.H., Armsworth, P.R., Barbosa, O. 
\& Gaston, K.J. (2008). Garden bird feeding predicts the structure of urban avian assemblages. Diversity \& Distributions, 14, 131-137.

Grey-Ross, R., Downs, C.T. \& Kirkman, K. (2009). Using housing estates as conservation tools: A case study in KwaZulu-Natal, South Africa. Applied Geography, 29, 371-376.

Gutzwiller, K.J. (1991). Estimating winter species richness with unlimited-distance point counts. Auk, 108, 853-862.

Kark, S., Iwaniuk, A., Schalimtzek, A. \& Banker, E. (2007). Living in the city: can anyone become an 'urban exploiter' Journal of Biogeography, 34, 638-651.

Liebl, A.L. \& Martin, L.B. (2014). Living on the edge: range edge birds consume novel foods sooner than established ones. Behavioral Ecology, 25, 1089-1096.

Liker, A., Papp, Z., Bákony, V. \& Lendvai, Á.Z. (2008). Lean birds in the city: body size and condition of house sparrows along the urbanization gradient. Journal of Animal Ecology, 77, 789-795.

McCaffrey, R.E. \& Mannan, R.W. (2012). How scale influences birds' responses to habitat features in urban residential areas. Landscape \& Urban Planning, 105, 274-280.

Nzama, S., Downs, C.T. \& Brown, M. (2010). Seasonal variation in the thermoregulation of house sparrows (Passer domesticus) in KwaZulu-Natal, South Africa. Journal of Thermal Biology, 35, 100-104.

Peacock, D.S., Van Rensburg, B.J. \& Robertson, M.P. (2007). The distribution and spread of the invasive alien common myna, Acridotheres tristis L. (Aves: Sturnidae), in southern Africa. South African Journal of Science, 103, 465-473.

Reis, E., López-lborra, G.M. \& Pinheiro, R.T. (2012). Changes in bird species richness through different levels of urbanization: Implications for biodiversity conservation and garden design in central Brazil. Landscape \& Urban Planning, 107, 31-42.

Robinson, R.A., Siriwardena, G.M. \& Crick, H.Q.P. (2005). Size and trends of the house sparrow Passer domesticus population in Great Britain. Ibis, 147, 552-562.

Seress, G., Bókony, V., Pipoly, I., Szép, T., Nagy, K. \& Liker, A. (2012). Urbanization, nestling growth and reproductive success in a moderately declining house sparrow population. Journal of Avian Biology, 43, 403-414.

Shaw, L., Chamberlain, D. \& Evans, M. (2008). The house sparrow; Passer domesticus in urban areas: reviewing a possible link between post-decline distribution and human socioeconomic status. Journal of Ornithology, 149, 293-299.

Shaw, L.M., Chamberlain, D.E., Conway, G.J. \& Toms, M.P. (2011). Spatial distribution and habitat preferences of the house sparrow, Passer domesticus in urbanised landscapes. British Trust Ornithological Research Report, 599, 4-23.

Sol, D., Griffin, A.S., Bartomeus, I. \& Boyce, H. (2011). Exploring or avoiding novel food resources? The novelty conflict in an invasive bird. PLOS ONE, 6, e19535.

Sol, D., Maspons, J., Vall-Llosera, M., Bartomeus, I., García-Peña, G.E., Piñol, J. \& Freckleton, R.P. (2012). Unraveling the life history of successful invaders. Science, 337, 580-583.

Taylor, B.W. \& Irwin, R.E. (2004). Linking economic activities to the distribution of exotic plants. Proceedings of the National Academy of Science U.S.A., 101, 17725-17730.

Yap, C.A.M. \& Sodhi, N.S. (2004). Southeast Asian invasive birds: ecology, impact and management. Ornithological Science, 3, 57-67. 
Copyright of South African Journal of Wildlife Research is the property of South African Wildlife Management Association and its content may not be copied or emailed to multiple sites or posted to a listserv without the copyright holder's express written permission.

However, users may print, download, or email articles for individual use. 